\title{
Emotional Ownership and Workplace Spirituality in Nigeria
}

\author{
Nwinyokpugi, Patrick Nkiinebari \\ Department of Office and Information Management, Rivers state University of Science and technology, Port \\ Harcourt, Nigeria
}

\begin{abstract}
Nigeria workplace has had accumulative incidences of gross laxity and unattached commitment to work due to the social divide between the goal of management and the interest of employees. This study focusses on achieving employees' commitment in the banking sector of Nigeria economy in the midst ofthis social dislocation between management of banks and banks staff in Nigeria. To realize this objective, the banks in south south region were covered in this study. 342 respondent employees of the banks sampled from the region provided the data gathered and amongst the dimensions, employee involvement, incentive and workplace equality were tested using SPSS 15.0. Findings revealed a correlation of the dimensions of emotional ownership and workplace spirituality and recommended that employees should be involved, adequate incentive strategies and equality and fairplay should be encouraged to enshrine workplace spirituality in the banking sector in Nigeria.
\end{abstract}

Keywords: Involvement, Incentive, Equity and Fairplay, Workplace Spirituality, Commitment

\section{Introduction}

Work in Nigeria to some is like just a means for survival and not a part of life. This is evident in the level of commitment the workforce gives to the work they do. Poor performance at work which is manifested in high employee turnover as well as high degree of hire and fire are causes for serious concern. There is frequent social distance between owners of business and workers, thus, employee alienation seems to be eroding the spirit of work that employees should commonly imbibe. This study attempts to x-ray this relationship gap between work and the workman. Spirituality is a state or experience that can provide individuals with direction or meaning, or provide feelings of understanding, support, inner wholeness or connectedness. Connectedness can be to themselves, other people, nature, the universe, a god, or some other supernatural power.

Spirituality in the workplace means that employees find nourishment for both the vertical and horizontal dimensions of their spirituality at work. Spirituality in the Workplace is about individuals and organisations seeing work as a spiritual path, as an opportunity to grow and to contribute to society in a meaningful way. It is about care, compassion and support of others; about integrity and people being true to themselves and others. It means individuals and organisations attempting to live their values more fully in the work they do. (Sparks \& Cooper, 1999)

Organisations with a strong sense of the horizontal concern will generally demonstrate some or all of the following: caring behaviors among co-workers; a social responsibility orientation; strong service commitments to customers; environmental sensitivity; and a significant volume of community service activities. The vertical and horizontal dimensions should be well integrated - so that motivations (sourced from the vertical) and actions (horizontal manifestations) are explicitly linked. We will be honoring organizations that are financially sound, sustainable, and effective, as well as focused on greater meaning and purpose. We believe that when done properly, Spirit at work enhances the overall value of the organization.

Attractive remuneration packages and perks are vital to retain employees but it may not necessarily motivate them to give their best to the company if there is no sense of emotional ownership towards the organisation. But Kher(2011) maintained that emotional ownership of work and a sense of belonging are enshrined when employees have high degrees of opportunities for self-expression, creativity in work, empowerment, freedom on job, opportunity to learn something new, variety in job and a sense of achievement.

In the Nigeria work place, organisations are plagued by a number of concerns such as rising costs, cut throat competition, corruption, job insecurity and employees' dissatisfaction due to thepsychological alienation that employees feel at work and more with the organisations they find themselves. When these happens the link between one's work and the organisational goals is broken and commitment and loyalty which represents the spirit of work also reduces. Individuals thus come to work for personal gains;seeking only for what the work can avail them more than what they can offer as work in the organisation. A person who likes his work may not like his organisation. A feeling of ownership towards the organisation does not come by offering Employee Stock Option Scheme but by making employees experience fairness, timely recognition of good work, trust and openness through transparent management, a caring approach, job security, freedom at work, a friendly work atmosphere and good career prospects.Alienation from organisation is the stumbling block in creating emotional 
ownership. An employee would give his best to the organisation only when he ownshis organisation emotionally.

The current Nigerian banking practise of hiring employees on short contracts is proving harmful not only to the organisations but also for the emotional well being of people and society at large, adding that "when the value of loyalty has become a thing of the past, linking job security to performance and increasing contract period should help". "It is management's responsibility to make the employees feel that they are wanted by the organisation and create a work atmosphere in which emotional ownership can thrive", it states, emphasising the need to change the mindsets of both leaders and employees.

\section{Related Literature}

According to Clark-Murphy, (2010) the person- environment approach suggests that for optimum productivity, individual should be compatible with the environment. The work environment include individual's expectations and perceptions regarding workload, control over ones work, tangible and intrinsic rewards of work, the relationship and sense of community among co-workers, perception of fairness in the workplace and role of personal and organizational values. The forces of globalization have substantially changed the nature and operation of the market place. The only imperative in such cases is to generate more money and indirectly demanding more work resulting in increase in the stress levels of the employees, leaving employees the problems of values and ethics in the organization are increasing and values are also demeaning day by day.

The findings of the various studies suggest that spirituality and emotional ownership plays a significant role in influencing the judgment, emotional and motivational qualities and decision-making in that frame of reference based on a connection with a transcendent and ultimate reality which is likely to be a source of solace, guidance, and inspiration to leader's ethical and critical decision-making.There is a strong linkage between employee development and the perception of ownership on the part of employees who see the development as support for their common existence with the enterprise. This is so in the sense that manpower is involved both in industrial harmony and social development. Whereas employees' supports and development creates the feeling of partnership and care, smooth and cordial relationship promotes interparty bond. A true spirit of ownership attitude becomes manifest in actions of employees and management as the absence of it is likely to bring relationship distance and the feeling of 'their work not my work' in employees. More so, that industrial peace enhances concerted concentration on development efforts. Industrial relation is primarily about negotiations, work environment and the utilization thereof.

\subsection{Involvement}

Employee involvement means that every employee is regarded as a unique human being, not just a cog in a machine, and each employee is involved in helping the organization meet its goals. Each employee's input is solicited and valued by his/her management. Employees and management recognize that each employee is involved in running the business" (Apostolou, 2000:2).Employee empowerment is a somewhat different concept. It means that in addition to involving employees in running the business, employees and management recognize that many problems or obstacles to achieving organizational goals can be identified and solved by employees. Employee empowerment means that management recognizes this ability, and provides employees with the tools and authority required to continuously improve their performance. The management states its expectations about employees recognizing and solving problems, and empowers them to do so."(Noor Sarooj and ArifSajjad2011). Participative management also known as participative decision making, has a lot of overlap with employee involvement. Participative management encourages the involvement of stakeholders at all levels of an organization in the analysis of problems, development of strategies, and implementation of solutions. Employees are invited to share in the decision making process of the firm by participating in activities such as setting goals, determining work schedules, and making suggestions. Other forms of participative management include increasing the responsibility of employees (job enrichment); forming self-managed teams, quality circles, or quality of work life committees; and soliciting survey feedback. Participative management, however, involves more than allowing employees to take part in making decisions. It also involves management treating the ideas and suggestions of employees with consideration and respect (Helms \&Cengage, 2006:1) Sashkin (1984) identifies four broad areas in which employees may participate under participative management: setting goals, making decisions, solving problems and making changes in the organization.

Participative management is based on four processes, each rooted in sharing: sharing information, sharing expertise, sharing discretion and sharing rewards (Helms \&Cengage, 2006). Sharing of information is concerned with keeping the employees informed about the economic condition, the goals and the performance of the firm. This helps employees understand the big picture, the significance of their tasks and how they contribute to the larger goals. The sharing of expertise in the form of training firstly helps to ensure that employees know how to interpret, evaluate and understand this information, secondly is concerned with allowing employees to develop the skills necessary to use the information to make effective decisions regarding 
the firm and thirdly allows for developing skills to further the careers of the employees. Sharing discretion allows employees, once they understand what the big picture is and how they fit in it, to decide for themselves how to best exercise their tasks to reach goals. For example allowing employees to set their own working hours. Sharing rewards is the increased compensation tied to achieving goals and introducing beneficial suggestions or ideas. Examples include Employee Stock Option Plans (ESOPs), companywide profit sharing programs and employee ownership of the firm.

\subsection{Equity}

Open communication internally and externally gives room for unrestricted appreciation of firms actions as well as inaction. Fuller participation of women and underrepresented groups proves that organization has equal opportunity for all actors in the work place. Open governance devolved power and responsibility for decisions. Individual freedom of expression and choice also provide the platform for equall opportunity for all concerns. Power is related to relationships versus structured meaningful work andworkplace democracy is not possible without unalienated and meaningful work (Mason, 1982: 102). Gender and ethnic equity tolerance, respect, inclusion of women and underrepresented groups are all ingredients for equity. When equity is restored at the workplace, bias and grievant tendencies are reduces and employee social connects is created between the work, the firms and the labour force. Psychological ownership of activities depends on worker contributions, knowledge and competence. More worker control over the functions that impact them "Reduce alienation, create a solidarity community based on work, strengthen attachments to the general good of the community, weaken the pull of self- interest and stimulate citizenship in the government of the enterprise itself (Dahl, 1985: 95). Individuals have control over their work tasks and innovations as well as ownership attitude is transferred into the work they do (Luhman, 2006). Improved trust and less fear,legitimacy for workers to question control are manifestations of a sense of belongingnesswhich actually builds the spirit of work in employees. (Markowitz, 1996) Enhanced flow of information Increase in organizational commitment, personal responsibility, ability to change (Harrison \& Freeman, 2004) Worker voice in job design, work requirements and quality. Because worker groups may not be privy to organizational strategies or have the required skills and knowledge they may make incorrect or less than advantageous decisions. Worker group decisions may take an inordinate amount of time and may disrupt normal operations (Harrison \& Freeman, 2004). Flatter, team-based organization structures Non-hierarchical controls (Luhman, 2006) Educate through participation thus inculcating democratic values in the citizens of the workplace (Grady, 1990) It is commonplace that industrial or business environment includes an atmosphere that is conducive for the execution of development programme of all sorts. It is pertinent to note that unions and employers, - whether at the government or the private sector or the individual level are partners in progress and it must be seen as such. The unions sometimes alert the employers on the need to put certain structures in place in order to accomplish the organizational goal and objectives.

\subsection{Incentives}

Stock options allow employees to directly engage in the ownership of a company. Stock options can be offered either as an optional paycheck deduction or via a voluntary investment-matching framework. Stock options are a helpful option in companies attempting to instill a long-term sense of loyalty among workers, who when heavily invested in company stock are more likely to take an interest in the success of each day-to-day business endeavor. Stock option incentives are also helpful for struggling companies, because they can bolster a struggling business through direct employee support; this is a particularly valuable strategy when other investors are in short supply. Stock options are not only in the best interest of the company during lean times; when a company is reporting healthy profits and share price increases, employees who have invested in stock options immediately can enjoy a tangible form of profit sharing. Shared growth between the company and employees via stock options has a positive effect on public relations and demonstrates to employees and the public that the company supports its workers and that supporting the company through purchasing its products is an investment in the local community.

Attractive remuneration packages and perks are vital to retain employees but it may not necessarily motivate them to give their best to the company if there is no sense of "emotional ownership" towards the organization (Kher, 2011). The factors contributing to "emotional ownership of work" and a sense of belonging are "opportunities of self-expression, creativity in work, empowerment, freedom on job, opportunity to learn something new, variety in job and a sense of achievement". This is what the Academic Staff Union of Universities (ASUU) in Nigeria has been doing in order to ensure that Nigerian Universities live up to their mandates (Fashina, 2005). Staff development enables smooth staff replacement to take place (Olasehun, 2005). This process becomes an unending cycle,and a well-developed manpower brings about psychological attachment of employees, in terms of relationship accommodation and resultant industrial harmony in organizations. 
All over the world, organisations are plagued by a number of concerns such as rising costs, cut throat competition, corruption, job insecurity and employees' dissatisfaction due to various reasons. "A combination of above mentioned factors can establish a link between one's work and the organisational goals," said the study based on emulative examples and exhaustive interactions in the industry. "A person who likes his work may not like his organisation. A feeling of ownership towards the organisation does not come by offering Employee Stock Option Scheme but by making employees experience fairness, timely recognition of good work, trust and openness through transparent management, a caring approach, job security, freedom at work, a friendly work atmosphere and good career prospects. Alienation from organisation is the "stumbling block in creating emotional ownership." An employee would give his best to the organisation only when he "owns" his organisation emotionally.The increased practice of hiring employees on short contracts is proving harmful not only to the organisation but also for the emotional well being of people and society at large. When the value of loyalty has become a thing of the past, linking job security to performance and increasing contract period should help.Noor and Arif (2011) maintained that workplace spirituality is a function of employees psychological attachment to the organisation they work so long as there is equity and fairness, adequate organisational incentives as well as workplace involvement of all employees in the work they do and relationships with the organisational structure.

\section{Methodology}

The study adopts a concurrent triangulation of research methodologies which includes both nomothetic (quantitative) and ideographic (qualitative) approaches. The population of the research includes all supervisory and junior level staff members of the banking industry, specifically the south-south region of Nigeria which comprises of six states: Akwalbom, Bayelsa, Cross River, Delta, Edo and Rivers from whicha total number of 4635 employees wasgenerated.Our sampling frame therefore consists of all managers and other employees of the banking industry, drawn from their head quarter branches across the south-south geopolitical zone which comprises of the six aforementioned states in the country Nigeria. From which we arrived at a sample size of 357. The sample size was determined using the krejcie and Morgan (1970) sampling table; while the population was sampled using stratified proportionate sampling methods based on the classification of banks (Sekaran, 2003).

\subsection{Research Instrument}

Two forms of data collection instruments were utilized, the questionnaire and structured in-depth interviews. The questionnaire was used in the retrieval of quantitative data with variables measured using five items (indicators) each, and opinions scaled on a five point likert scale ranging from strongly disagree (1) to strongly agree (5).For our qualitative data, interviews were conducted on ten respondents drawn from the sample. All responses and field recordings were later transcribed and saved in rich text formats (rtf), coded and analysed using the QSR Nvivo software. As a result of various unforeseen and uncontrollable factors, some of the questionnaire were, on retrieval, considered unusable and lacked the necessary credibility for inclusion in the research process. This was as a result of a great number of missing values and incoherent responses. This left a response rate of 342 which still gives $96 \%$ level of response.

\subsection{Validity and Reliability}

The cronbach alpha which is an interitem consistency measure of reliability was used, giving us a coefficient of (0.973) for Emotional Ownership and (0.969) for Workplace Spirituality.For the validation of the instrument, the content validity was adopted. This ensures that the items indicated within the measure adequately captures the intent of the concept (Sekaran, 2003).

\subsection{Findings}

The findings of this study are presented and discussed as it affects three major and important areas namely, the demographic, the univariate and the bivariate. The quantitative analysis occupies a predominate position as the qualitative data is used primarily to support and enrich the nature of the research. 
Table 1.Showing Demographic Frequencies

\begin{tabular}{llcc}
\hline Variable & Categories & Frequency & Percentage (\%) \\
\hline Gender & Male & 197 & 58 \\
\hline & Female & 145 & 42 \\
\hline Qualification & Total & $\mathbf{3 4 2}$ & $\mathbf{1 0 0}$ \\
\hline & Diploma & 115 & 34 \\
\hline & First Degree & 191 & 56 \\
\hline Mrganizational Level & Total & 36 & 10 \\
\hline & Managers/Supervisory & $\mathbf{1 0 0}$ \\
\hline Others Staff & $\mathbf{3 4 2}$ & 13 \\
\hline Tenure & Total & 298 & 87 \\
\hline & Less than five (5) years & $\mathbf{1 0 0}$ \\
\hline 6-10 years & 106 & 31 \\
\hline & $11-15$ years & 195 & 57 \\
\hline & Total & 41 & 12 \\
\hline & Christianity & $\mathbf{3 4 2}$ & $\mathbf{1 0 0}$ \\
\hline
\end{tabular}

Source: SPSS output

Our demographic data show a higher amount of male (58\%) employees in comparism to their female $(42 \%)$ counterparts within the banking industry; a close marginal difference when compared to other sectors of the Nigerian economy, especially manufacturing (Asawo, 2009).Also as a result of the religious disparity between the north and south of Nigeria, a huge gap can be observed, with Christianity response rates making up for $96 \%$ of the total sample and Islam $4 \%$. This is possibly due to the geographical location of the study, which focused on the south-south of Nigeria, known for its Christian popularity.

Table 2. Showing the UnivariateAnalysis of the Study

\begin{tabular}{lcccccc}
\hline Variable & Mean & $\begin{array}{l}\text { Standard } \\
\text { Deviation }\end{array}$ & Skewness & & Kurtosis \\
\hline $\begin{array}{l}\text { Emotional } \\
\text { Ownership }\end{array}$ & Statistic & Statistic & Statistic & Std.Error & Statistic & $\begin{array}{c}\text { Std. } \\
\text { Error }\end{array}$ \\
\hline Involvement & 4.0754 & 0.93635 & -1.741 & 0.132 & 2.375 & 0.263 \\
\hline Equality & 4.1012 & 0.82238 & -2.095 & 0.132 & 3.963 & 0.263 \\
\hline Incentive & 4.1088 & 0.83717 & -2.391 & 0.132 & 5.417 & 0.263 \\
\hline $\begin{array}{l}\text { Workplace } \\
\text { Spirituality }\end{array}$ & Statistic & Statistic & Statistic & Std.Error & Statistic & Std. \\
\hline Mutuality & 4.0596 & 0.80479 & -2.181 & 0.132 & 5.088 & 0.263 \\
\hline Trust & 3.9889 & 0.81092 & -1.780 & 0.132 & 3.234 & 0.263 \\
\hline Harmony & 4.1152 & 0.77403 & -2.171 & 0.132 & 4.774 & 0.263 \\
\hline
\end{tabular}

Source: SPSS output

The results show high mean scores, indicative of the presence of the various positive factors of emotional ownership and workplace spirituality within the Nigerian banking industry. With a mean score of 4.0754, respondents feel they are, in various ways, involved in the banking process and play important roles.Equality carries a mean score of 4.1012, indicative of workers feelings of fair treatment and regard within the banks and incentive with a mean score of 4.1088 also shows that on the average, most Nigerian banking workers feel they are well compensated for their efforts and contributions to their organizations.Under workplace spirituality, Mutuality which is indicative of cooperativeness and agreeability within the work environment carries a high mean score of 4.0596, while trust within the work environment as perceived by the employee carries a mean score of 3.9889. This is the lowest score but still an adequate indication of good trust within the banks, Harmony which indicates oneness and unity also holds a high mean score of 4.1152. Also as observed from the table, all standard deviation scores are very low with the highest score at 0.93635 , this shows a low level of disagreement in responses as well as dispersion from the average mean score. Also the table shows that the data is negatively skewed and also leptokurtic $(\mathrm{k}-3>0)$ in nature. 
Table 3.Showing bivariate analysis using Spearman's rank ordercorrelation

coefficient.

\begin{tabular}{llccc}
\hline \multirow{2}{*}{ Equality } & & Mutuality & Trust & Harmony \\
& Rho value & 0.597 & 0.718 & 0.732 \\
\cline { 2 - 5 } Involvement & P-value & 0.000 & 0.000 & 0.000 \\
& Rho value & 0.751 & 0.678 & 0.587 \\
\cline { 2 - 5 } Incentive & p-value & 0.000 & 0.00 & 0.000 \\
& Rho value & 0.715 & 0.685 & 0.626 \\
\cline { 2 - 5 } & p-value & 0.000 & 0.000 & 0.000 \\
\hline
\end{tabular}

Source: SPSS output.

The study adopts a 0.05 level of significance at a $95 \%$ confidence interval. The table above shows significant and positive relationships between the empirical referents of Emotional ownership and the criterion measures of Workplace spirituality, with rho values as high as 0.751 which is indicative of the strength and direction $(+)$ of the relationship and $\mathrm{P}$-values at $0.000(\mathrm{P}<0.05)$ which shows that there is a positive relationship between Emotional Ownership and Workplace Spirituality.

Our qualitative analysis showed that most of the respondents acknowledged a high level of support from management as well as inclusion in various decision making processes. Although they opined for more effort in the area of incentives, most agree that they are well motivated and compensated for their efforts. The analysis is herein depicted in the following qualitative model:

Figure 1.RrelationshipBetween Employee Ownership and Workplace Spirituality.

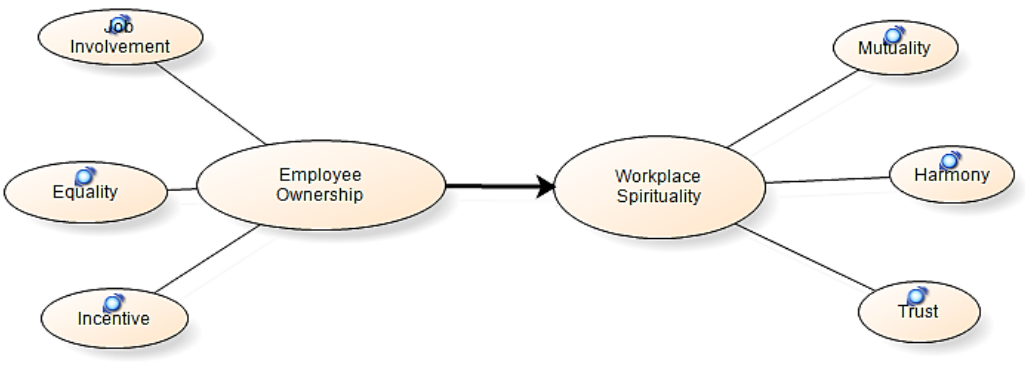

IV. Managerial Implications Of The Study

An important implication of this study is the identification of the role of a participative-management style, recognition of performance, adequate reward systems and equal opportunity for all concerned in achieving a more conducive, peaceful and harmonious workplace or environment. It is recommended that management, in areas necessary, organize for such participative organisms such as team briefings, quality circles and such programs that grant employees contributory avenues and opportunities to make input especially in areas that concern their jobs and roles.

Also it is recommended that policies which advocate for equality and fair treatment of all staff concerned with regards to performance appraisal, recruitment, promotion, responsibilities and reward be taken seriously and implemented with necessary feedback and control systems.

\section{Conclusion}

Emotional ownership makes an employee more committed towards his work and leads to more job satisfaction and in turn reduces the job stress. The study found that attractive remuneration packages and perks are vital to retain employees but it may not necessarily motivate them to give their best to the company if there is no sense of "emotional ownership" towards the organization. Leadership plays an important role in increasing emotional ownership. If a leader is a good communicator, he employs positive relationship tools to attract employees partnership and belongingness and employees thus feel a sense of being connected to the organization, this enhances more emotional ownership.

Emotional ownership makes the employee more satisfied and reduces his stress levels. If employees will be provided incentives, fringe benefits, sense of belongingness, trust, better career opportunities, opportunity for growth, freedom of self expression then they will be more satisfied with their jobs and will be more attached to their organizations emotionally. This will help in increasing organizational emotional ownership. 
The sense of ownership and satisfaction within the employees will help in increasing commitment towards work and reducing stress levels within the employees. Similarly spirituality at organizational level helps to understand the problems at societal level covering managerial and executive issues and lead to lesser amount of conflicts and more commitment towards the work. Organizational emotional ownership evolves workplace spirituality and job satisfaction and thus, enhances industrial harmony.

Positive and achievement driven communication also create emotional ownership in employees of organizations. According to Berne(1961) communication is critical to either keeping a workforce and exiting them. To keep a good workforce who will key into the vision and mission of your organization, management need to speak well of them, make them see the firm as theirs, the tasks as a life they have to live and as well see the life of the firm as theirs. For Berne, when employees sees the firm as part of life they show more commitment and would not be part of letting it go down.

\section{References}

[1] Sparks, K. And Cooper, C.L., Occupational differences in the work-strainrelationship: towards the use of situation specific models. Journal of Occupational and Organisational Psychology, 721999, 219-29.

[2] KherManik, The Culture of Emotional Ownership- A rainbow towards organizational transformation. (Ane Books Pvt. Ltd. 2011)

[3] Clark-Murphy, D. Do interactive theories really explain public sector managerial decision making? Asian Social Sciences, 6(3),201017-26

[4] Noor Sarooj and ArifSajjad, Achieving Job Satisfaction via Workplace Spirituality: Pakistani Doctors in Focus. European Journal of Social Sciences, 19(4),2011 507-515.

[5] Helms, Marilyn and Cengage, Gale, Encyclopedia of Management: Leadership Theories and Studies(2006); [On-line] US: Available: http://www.enotes.com/management -encyclopedia/leadership Theoriesstudies Accessed January 5, 2010

[6] Sashkin M, Participative Management is an Ethical Imperatives, Organisational Dynamics 1984, 12, 4: 22

[7] Dahl, R.A. A preface to economic democracy. (Berkeley University of California Press.1985)

[8] Luhman, J.T..Theoretical postulations on organization democracy.Journal of Management Inquiry, 15(2), $2006,168-185$.

[9] Markowitz, L.. Employee participation at the workplace: Capitalist control or worker freedom? Critical Sociology, 22(1), 1996, 89103.

[10] Harrison, J.S., \& Freeman, R.E.. Democracy in and around organizations: Is organizational democracy worth the effort? Academy of Management Executive, 18(3), 2004, 49-53.

[11] Grady, R.C. Workplace democracy and possessive Individualism. Journal of Politics, 52(1), 1990, $146-166$.

[12] FashinaOladipo,Equality and Priority in the Distribution of Health Resources. In Proceedings of WHO Research Group Conference on Health Issues in Allocation, Fairness and Goodness 2000

[13] Girigiri B. K., Understanding work and work values in employees, Journal of Social sciences vol 2(4),2005, pp 21-28,

[14] Sekaran M., Research Methods for Business, A Skill Building Approach, $4^{\text {th }}$ Ed New Jersey 2003

[14] Asawo, S.P Spiritual Leadership and Workers Commitment, Phd Thesis in Management, Rivers State University of Science and Technology, 2009

[15] Berne, Eric. Transactional Analysis in Psychotherapy.(Grove Press, Inc., New York, 1961. Page 4) 